\title{
Song and music in the Pauline epistles Paul's utilisation of Jewish, Roman and Greek musical traditions to encourage the early Christian communities to praise God
}

Francois P. Viljoen

School for Biblical Studies \& Bible Languages

Potchefstroomse Universiteit vir $\mathrm{CHO}$

POTCHEFSTROOM

E-mail: sbbfpv@puknet.puk.ac.za

\section{Abstract}

Song and music in the Pauline epistles. Paul's utilisation of Jewish, Roman and Greek musical traditions to encourage the early Christian communities to praise God

This article presents an exegetical investigation of several Pauline texts in which he encourages early Christian communities to praise God with song and music. Paul encourages the congregation in Rome to praise God in unity. The Colossians and Ephesians are exhorted to sing in order to instruct and to admonish one another to glorify God. Furthermore Paul remarks on hymn singing in the Corinthian congregation. In this article it is indicated that influences from Jewish, Roman and Greek cultures in these different communities are probable. Each of these three cultures had a long musical tradition and thus the content and typical features of their musical traditions are investigated. Furthermore, the issue whether Paul utilised features from these musical traditions to encourage the early Christians to praise God with song and music is also explored. The article concludes that insight in these features results in a better understanding of Paul's teaching with regard to the use of song and music in Christian worship - also for today. 


\section{Introduction}

In Romans 15:9-12 Paul encourages the Christian congregation to praise God with song and music. In this regard the following should be noticed:

- He quotes from the Jewish Scriptures;

- he quotes in Greek; and

- he addresses a congregation in the centre of the Roman world.

Each of these three cultures had a long musical tradition. The question arises as to what extent Paul utilises Jewish, Greek and Roman musical traditions to encourage the congregation.

In 1 Corinthians 14 Paul again refers to song and music utilized by the congregation in his explanation of the function of the gifts of the Spirit in the church. His exhortations to sing are found again in Colossians 3:16 and Ephesians 5:19.1 It is therefore a question whether and to what extent Jewish, Greek and Roman musical traditions are reflected in these three passages.

\section{The context of Jewish, Greek and Roman musical traditions}

During the expansion of the Roman world in the Western Mediterranean, the influence of the Hellenisation and a strong intercultural exchange developed between peoples of all countries. With regard to music it was also the case (Abraham, 1985:37). It is not possible for us to know exactly what and how much of each tradition respectively was implied in Paul's admonitions. It is clear, however, that strong influence from the Jewish, Greek and Roman traditions were implied in Paul's writings (Grout, 1960:19-20).

Till the beginning of the nineteenth century Paul's authorship of the letters to the Colossians and Ephesians was commonly accepted. There is no evidence that the Pauline authorship of these epistles was ever disputed until that time. However, since 1820 many scholars became skeptical to accept that Paul was genuinely the author of Colossians and Ephesians. Questions were raised with regard to the so-called unusual language and style found in these letters, the theology of these letters differing from the other letters of Paul and the strong correlation between Colossians and Ephesians (Floor, 1995:11; Guthrie, 1970:507, 554). Although all these objections are considered, it remains difficult to overthrow the overwhelming external attestation to Pauline authorship, and the Epistles' own claims. To maintain that a Paulinist composed the letter, but effaced himself and attributed it to Paul, as well as the assumption that the church recognised it as such, is considerably less credible than the simple alternative of regarding it as Paul's own work. 
In order to understand some musical features and practices that Paul describes, it is important to be knowledgeable of the musical traditions to which he might have referred.

\subsection{Jewish musical traditions}

Because of its inescapable cultural environment, early Christianity had a specific heritage in the music and ritual of the Jewish temple and synagogues. Early Christian writings testify that the first Christian congregations adopted the Jewish ritual of daily prayer hours as well as the custom of singing psalms in their services (Lamb, 1962:9; Oesterley, 1965:99,149; Viljoen, 1990:61).

The Jewish people had a strong musical tradition (Abraham, 1985:39). The origin of their music is ascribed to Jubal "the father of all those who play the lyre and pipe" (Genesis 4:21). From archaeology we know that Jewish music is very old. Music had already been relatively developed as early as the third millennium BC (Sachs, 1943:57). Reading the ancient history of Israel in the Pentateuch (e.g. Exodus 15), it is evident that Israel was used to singing during religious and national feasts (Bloem, 1985:48). At times of celebration and in times of lamentation Israel sang.

Before the monarchy a more simple type of music existed in which emotion and free effusion shaped the patterns of melody and rhythm. In the time of King David, singing was professionally organised, and he appointed professional musicians from the house of Levi for that purpose (1 Chronicles $6: 31 ; 16: 5-7 ; 23: 5)$. Solomon continued this development (2 Chronicles 5:11-13). More complex forms of music developed as a result of more complex forms of political and cultic institutions (Van Dyk, 1991:374). In Jerusalem guilds of professional musicians (e.g. sons of Korah) were established. At the time of the establishment of the monarchy and the building of the temple of Solomon, the quality of the music of Israel was raised to a higher level (Sachs, 1943:59).

After the Babylonian exile, music played an even more important part in temple worship than before. Some scholars note that many of the developments, which took place after the Babylonian exile, were projected back into the past. Many of these later developments were ascribed to David and Solomon (Van Dyk 1991:375). The temple singers were highly organised, some played instruments, others sang. According to Abraham (1985:39) something like a liturgical calendar even emerged: Ps. 24 the first day of the week; 48 on the second; 82 on the third, 94 on the fourth, 81 on the fifth, 93 on the sixth, 92 on the Sabbath, and 30 annually on the anniversary of the "dedication of the House of David" (also see Lamb, 1962:12-16). It is in this situation that the form of the 
book Psalms came into existence. Although many of the Psalms were much older and had been handed over for generations, as well as being incorporated into smaller collections earlier, they were combined into one book. The book of Psalms can therefore be described as the songbook of the congregation of the second temple (Van Dyk, 1991:376).

After the fall of the temple in $70 \mathrm{CE}$, much of its practices, including its musical traditions, were continued in the synagogues (Abraham, 1985: 39; Louw, 1981:68). For many Jews in diaspora the synagogue was regarded as some kind of a substitute for the temple. The liturgy of the synagogues in different places deviated, however, in different ways and intensity from that of the temple. In some places the liturgy was even influenced by Greek religious practices (Höweler, 1951:14). It is, however, certain that the synagogal liturgy was based on that of the temple (Oesterley, 1941:214-215).

There is ample evidence as to the central elements in the synagogal liturgy as being based on the temple ceremonies (Philo, Vita Mos. iii. 216; Josephus, Antiq. xvi. 43, Contra Apion. iii. 216). The most important aspect of the liturgy was teaching (it centred in the reading of the Law and the Prophets). Scripture reading was followed by the discourse. Prayer, as well as the priestly blessing was also an essential element. The congregational amen was uttered after each of the three sentences of which the priestly blessing was composed. The singing, or saying of Psalms, was another element in the synagogal service.

Paul was accustomed to Jewish religious rituals. He thus introduced himself: "I am a true born Jew ... a native of Tarsus in Cilicia. I was brought up in this city, and as a pupil of Gamaliel I was thoroughly trained in every point of our ancestral law" (Acts 22:3). As Paul proclaimed Christianity as the fulfilment of expectations of the Jewish religion, he therefore unmistakably would have had the rich Jewish musical traditions in mind when writing to the early Christian communities about song and music in the church.

The most important musical traditions that he most probably had in mind, are the following.

Among the Hebrews, songs were sung in different forms of alteration (Oesterley, 1965:75 ff). Among these was responsorial psalmody by which the leader sang the first line(s) and the congregation responded by singing the following line(s). In such a way, parallel phrases were sung. A thought was restated, continued or amplified by the responding participant (eg. Psalm 103; 118; 136). Alteration was also done by anti- 
phonical psalmody, in which two parts of a verse, or alternate verses, were sung in turn by two choruses (Fohrer, 1968:263).

Another familiar way of "singing" was the reciting of passages from Scripture by a soloist, using melodic formulas (Grout, 1960:20; Keuchenius et al., 1977:9-10). In many cases the recitation was answered with outcries like "Hallelujah", "Amen", or "Hosanna" (Schlier, 1969:264).

Paul should have been accustomed to the musical instruments of the Jews. To identify all the musical instruments in the Old Testament is a mammoth task (see Jones, 1986:101-115 for a complete treatment). From pictures and archaeological finds we can list the different musical instruments as follows:

- idiophones (these are clapping, banging and shaking instruments: e.g. shakers, rattles, cymbals, sistrums and castanets);

- membranophones (these are different types of drumming devices: e.g. the hand-drum, tambourine and kettledrum);

- aerophones (these are blowing instruments: e.g. flutes, trumpets and the horn); and

- cordophones (these are string instruments: e.g. the lyre, harp and lute).

Music had different functions in the Old Testament. With the help of music, the ancient prophet delivered his oracle. In 2 Kings 3:15 it is said, for example, that the hand of God came upon Elisha while music was played and that he prophesied. From 1 Samuel 16:14-23 and 18:10 it is clear that the Israelites attributed powers to music. David was commanded to play for Saul, and consequently calmed the evil spirit within him.

A wide variety of Jewish songs are known from the Old Testament, too many to mention. Apart from the compiled book of the Psalms, one should also take note of songs like those of Moses (Exodus 15:1-19 and Deuteronomy 32:1-42), the Prayer of Hanna (1 Samuel 2:1-10), the Prayer of Habakuk (Habakuk 3), the Prayer of Isaiah (Isaiah 26:9-20), the Prayer of Jonah (Jonah 2:3-10) and the songs of the three young men (Daniel 3:26-83). From these passages it is evident that religious music did not belong to the temple alone. Religious songs existed for every occasion: personal prayers, love songs, funeral songs, war songs, working songs, drinking songs, songs praising God, songs to be sung during sacrifice and songs for specific festivals. Music and singing was part of the formal institutionalised cult as well as the informal religions of everyday life. Music covered every sphere of life in Ancient Israel and 
could be described as humankind's response to the world and to God. Not only was it sung by the priests or Levites, it was the "voice" of the people.

It is therefore necessary to take into consideration the Jewish musical traditions when investigating the meaning of Romans 15:9-12, 1 Corinthians 14:15-17, 26, Colossians 3:16 and Ephesians 5:19 where Paul refers to song, music and musical instruments and elements.

\subsection{Greek musical traditions}

Paul grew up in the cosmopolitan city, Tarsus. Many scholars regard this city as the centre of Greek religion and culture in Paul's days (cf. Floor, 1978:4). Surely he was acquainted with Greek civilisation. As Greeks and Hellenistic people became converted to the Christian faith, it is most probable that Paul, in his argumentation on music, also accumulated musical elements from their Greek traditions.

Greek mythology ascribed a divine origin to music and named as its inventors and earliest practitioners gods and demigods, such as Apollo, Amphion and Orpheus. The Greeks were the only people to lay stress on the musicianship of some of their divinities. Gods and men alike made music, finding in it a noble form of expression (Wörner, 1973:50). The word music had a much wider meaning to the Greeks than it has for us (Abraham, 1985:27). Music was the adjectival form of Muse. In classical mythology the Muse were the nine daughters of Zeus and Mnemosyne who presided over arts and sciences. They sang and danced during feasts of gods under guidance of Apollo (Keuchenius, 1977:16). The verbal relation between Muse and music suggests that among Greeks music was thought of as something common or basic to activities that were concerned with the pursuit of truth and beauty (Grout, 1960:7). From earliest times music was an inseparable part of religious ceremonies and had a strong ethical character (Höweler, 1951:17; Sokolowski, 1959:215 ff). These ceremonies were held to honour the gods and to celebrate their truth, beauty and influence on the cosmos and on human beings.

In the cult of Apollo the lyre was the characteristic instrument. This instrument was used to create calmness and harmony, which was associated with the Apollo cult. Very much in contrast to the cult of Dionysos, the aulos was the characteristic instrument (Abraham, 1985:25; Kloppenburg, 1963:2-33). This instrument tended to produce excitement and enthusiasm associated with the Dionysos cult. Both these instruments were used for solo playing and accompanying singing and the reciting of epic poems (Grout, 1960:8-11). The myth of the 
competition between Apollo with his lyre and Marsyas with his aulos reflects the clash between the two different musical attitudes. Apollo was victorious. The lyre (and other cordophones) and the aulos were distinctive of two essentially different forms of musical activity. These two were not used together until the rise of tragedy in the 5th century (Wörner, 1973:42).

Friedrich Nietzsche in Die Geburt der Tragodie (1917) indicated two attitudes in the Apollonian and the Dionysian concepts of music. These attitudes towards art were separate in both origin and aim (Wörner, 1973:43). He assigned the Apollonian principle the realm of dream, of the beautiful light of the inner imaginative world, of higher truth, of measure, of simple transparent beauty, and of the individual. To the Dionysion concept he attributed intoxication, forgetfulness of self, magic transformation, excess, mystic feeling of identification, titanic and barbaric lust for life, and universality. Thus the Apollonian concept is regarded as that of a supra personal, quiet, and reserved type of artistic attitude. The Dionysian concept is regarded as subjective, uninhibited and orgiastic.

In the Greek musical tradition a close unity between melody and poetry existed (Keuchenius et al., 1977:16). Greek music was almost always associated with words or dancing or both. This ruled out a purely contemplative or passive aesthetic enjoyment of music. Song unequivocally possessed pre-eminence. The really sonorous aspect of music was called melos. According to Plato, melos was composed of logos (word), harmonia (modulation - that is the relation in terms of tension between successive tones - and rhythmos (movement). Tone and rhythmos had to subordinate themselves to the word (Wörner, 1973:42).

The melody and rhythm of music were most intimately bound with the melody and rhythm of poetry. A poet was a composer and vice versa. As a matter of fact, poetry and music were practically synonymous. Lyric poetry was poetry sung to the lyre. Tragedy implies that the verb a $\delta \in L \nu$ (to sing) is incorporated. Many Greek words that designate different kinds of poetry, such as $\omega \delta Z$ (ode) and $v \mu \nu \hat{o}$ (hymn), are in fact musical terms. Forms that lacked music were not designated at all. In the beginning of his Poetics, Aristotle, after setting forth melody, rhythm and language as the elements of poetry, continues to say: "There is further an art which imitates by language alone, without harmony, in prose or in verse ... This form of imitation is to this day without name" (I, 1447.28). Therefore Greeks were in search of the perfect union of words and music. Music and words were seen in a complementary relationship. Words were seen as rational while sounds were regarded as emotional. It was assumed that when used correctly in union, it could have an 
immense influence. The composition and performance of this kind of music (Greek amusement) was regarded as a highly developed science rather than a mere form of amusement (in the modern sense of the word).

Greeks attributed strong power to music. People thought "amusement" (by music) could heal sickness, purify the body and mind, and work miracles in the realm of nature. Music created a katharsis (cleansing) of the ethos (Höweler, 1951:24). They believed in the existence of a power in music akin to the power of words that could influence human thought and action. According to the Greek view on music an artist had the obligation to exercise this power with due regard for its effect on others. This probably was the most important aspect of Greek thought about music. The sound combination of music plus words was seen to have a strong ethical effect. Music was not to be used alone or merely to create an emotional effect.

Music had a dominant role as the moral pillar of the political and educational structure. According to the Greek view of music, depending on its particular kind, music had a positive or negative effect on the human will. Pythagoras, for instance, argued strongly that humans should take cognisance of the ethos or the moral qualities and effects created by music, as music was regarded as a force that could affect the universe. Accordingly Pythagoras was supposed to have charged aulos playing with being undisciplined, ignoble and harmful (Wörner, 1973:52). Hence the attribution of miracles to legendary musicians of mythology. Music was conceived as a system of musical sounds and rhythms that exemplified the harmony of cosmos and humans corresponding to it. Music was thus regarded as having an ethical and therapeutic effect on the will and thus the character and conduct of human beings.

According to Aristotle music imitates (represents) the passions of the soul, i.e. gentleness, anger, courage, temperance, and their opposites. Hence, when one listens to music that imitates a certain passion, he becomes imbued with the same passion. If over a long time he habitually listens to the kind of music that imitates noble or ignoble passions, his character will be shaped accordingly. Thus, if one listens to the wrong kind of music, he will become the wrong kind of person, and conversely.

Different kinds of music affect character in different ways. Some music tends towards calmness and upliftment. This was typical in the worship of Apollo, where the lyre was used as instrument along with the ode and epic poetry. Other music tends to produce excitement and enthusiasm. This was typical in the worship of Dionysos, where the aulos was used in combination with dithyramb and the drama. 
Plato and Aristotle were quite clear as to what they meant by a "right" person, that is a person who is able to practise self-discipline ( $\dot{\epsilon} \gamma \kappa \rho \dot{\alpha}-$ $\tau \in(\alpha)$. The way to produce such a "right" person was through the system of public education in which the two principal elements were gymnastics and music. One was suitable for the discipline of the body and the other for that of the mind. It was important to balance these two elements. "Mousike" was good for the soul and gymnastics for the body (Abraham, 1985:32-33; Kloppenburg, 1963:28).

Plato wrote: "Let me make the songs of a nation and I care not who makes the laws" (Republic, III, 398 ff; Laws, VII, 812E) while Aristotle argued that music used to educate the young, should be regulated by law (Politics, 5-7).

Musical performances, however, were mostly improvised. The skilled performer was, to a certain extent, also the composer. For specific circumstances and needs, the musician could improvise accordingly. This music was composed according to one of the many individual artistic forms. The hymnos, for example was a lofty art song for the gods or late heroes, usually accompanied by a stringed instrument. Also the living heroes were entertained at their banquets with song with aoidoi, which were heroic songs believed to have originated directly from divine inspiration - an idea that went back to the conception of the magical force of music (Viljoen, 1990:219-220; Wörner, 1973:50).

A closer examination of the musical references in Romans 15:9-12, 1 Corinthians 14:15-17, 26, Colossians 3:16 and Ephesians 5:19 thus reveals that it is also important to take these Greek musical traditions into consideration.

\subsection{Roman musical traditions}

We have no authentic remains of Roman music, but only second-hand information from accounts of performances and theoretical treatises. From these accounts it is uncertain whether Romans made any significant contributions to the theory and practice of music. They seemingly derived most of their art music from Greece, especially after that country became a Roman province in 146 BC (Kloppenburg, 1963: 34; Wörner, 1973:55, 58). During the period of Hellenism Roman culture was suffused with the Greek cultural heritage. This imported culture replaced much of the indigenous Etruscan and Italian music. The result was that Rome did not make much of an independent contribution to the history of music. In comparison with the Jewish and Greek musical traditions, the discussion of the Roman traditions will therefore be very brief. 
From the writings of Cicero and Quintilian it is clear that familiarity with music was considered as part of the education of a cultivated person (Grout, 1960:18). There are reports of the popularity of virtuosos, the prevalence of large choruses and orchestras, and grandiose musical festivals and competitions. Singing in every phase of social activity, such as at work, recreation, worship is described, as well as the role of festive songs, satirical songs, love-songs and drinking songs. Many emperors were patrons of music. Nero even aspired to personal fame as a musician.

Romans invented or developed music chiefly for military purposes. For this purpose some brass instruments of trumpet and horn types were developed. Their innovations were limited to the trumpet family. These instruments were used in the first place for military signals but also in religious ceremonies (Abraham, 1985:42).

To a lesser extent than in the Jewish and Greek musical traditions, Roman traditions should be taken in consideration in an investigation of possible influences in passages in which Paul refers to song and music. It should not be neglected, however.

\section{Influences in Christian music?}

Within the context of the Jewish, Greek and Roman musical traditions, passages in which Paul refers to song and music are investigated in this section of the article. It will be attempted to determine to what extent these traditions had influenced his consideration on these issues. The musical traditions also contribute to the understanding of these passages.

\subsection{Romans 15:9-12}

In Romans 15:6 Paul encourages the congregation to praise the God and Father of our Lord Jesus Christ with one mind and voice:

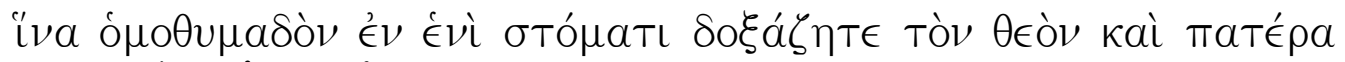

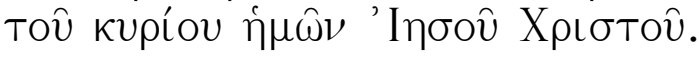

(So that with one heart and mouth you may glorify the God and

Father of our Lord Jesus Christ.) ${ }^{2}$

His readers were the Christians in Rome $(1: 7,15)$. It seems as if most members of the church consisted of non-Jews. However, there must have been a considerable number of Jews in the church of Rome as well (Pelser, 1984:44-45).

English translations of the Greek text are taken from the New International Version. 
The encouragement in Romans 15:6 is part of Romans 15:1-13, which forms an antithetical correlation with Romans 1:1-17 (Du Toit, 1993:6977). In Romans 1:1-17 the nations are described as denying God his glory. In Romans 15:1-13, in contrast, people who glorify Him are described. In Romans 1:18-21 the essence of the iniquity of the heathen nations is identified as their refusal to glorify and thank God as God. In Romans 15:1-13 the church, however, is depicted as a doxological community. This doxological function is the church's reaction to the mercy of God (Romans 12:1).

It is significant how strongly Paul emphasises unity within the doxological community (Cranfield, 1985:396). Romans 15:5-6 describes a prayer for unity of mind in the congregation by following the example of Christ's self-denial, in pleasing others for their good, to build up their faith, so that with one heart and mouth the congregations may praise the God and Father of our Lord Jesus Christ. The prayer aims at and implies singing in unison with strong and weak believers, Jews and Gentiles, united in their praise of God and in making one another happy, instead of despising or condemning one another (15:1-3, 8-9, 14:3,10) (Saa, 1993: $510 \mathrm{ff}$.$) .$

The influence of Jewish traditions is remarkable in Paul's encouragement of the community to praise God in unison. In Romans 15:9-12 he quotes four passages from Jewish Scriptures, viz. the Law (Torah) (Deut. 32:43), the Prophets (Nebiim) (Is. 11:20, 2 Sam. 22:50) and Writings (Ketubim) (Ps. 18:50; 117:1). Paul's acquaintance with these passages and songs testifies to their influence in his thinking and religious practice.

\section{- Romans 15:9:}

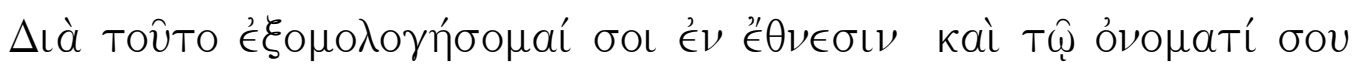
$\psi a \lambda \omega \hat{\omega}$. (Ps. 18:50 [17:49, LXX³])

(Therefore I will praise you among the Gentiles; I will sing hymns to your name.)

The first of the four supporting Old Testament quotations is from the Writings. The phrase is structured according to a typical Jewish parallelism. Paul cites David's song of royal thanksgiving as proof of God's saving will to join Jew and Gentile in praise. According to this quotation it was David's desire that the nations become acquainted with his Lord who delivered and enthroned him. Therefore he tells them about the Lord by singing by accompaniment. Paul may have seen in the psalmist's 
words a foreshadowing of his own mission as the Jewish apostle of the Gentiles (Cranfield, 1979:745)

- Romans 15:10:

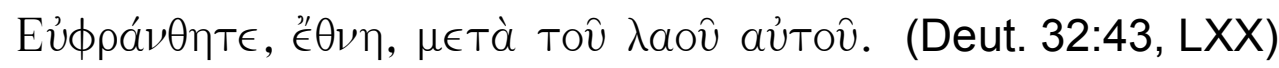

(Again, it says, rejoice, O Gentiles, with his people.)

Paul takes his second supporting quotation from the Law. In this song of Moses the Gentiles are summoned to join Israel, rejoicing in God's salvation of his people. Paul quotes this song to substantiate his admonition that Jews and Gentiles should accept one another to glorify God in unison, implying joyful singing together in the congregation.

\section{- Romans 15:11:}

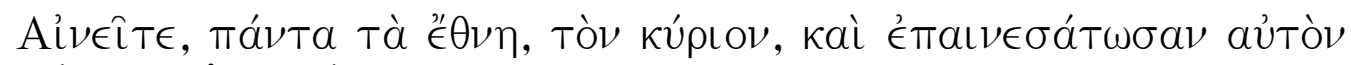
тávTES oi $\lambda a o^{\prime}$.

(Ps. 17:1[116:1 LXX])

(Praise the Lord, all you Gentiles, and sing praises to him, all you peoples.)

This song is a post-exilic psalm from the Writings which calls on all the nations of the world to sing the praise of the graceful and faithful Lord of the covenant. Paul utilises this post-exilic psalm, with its repetition of "all" in two parallel phrases, to call on Jews and Gentiles to sing the praise of the Father of our Lord Jesus Christ with one heart.

\section{- Romans 15:12:}

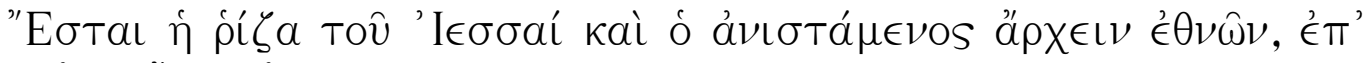

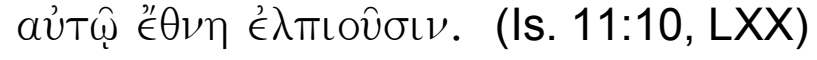

(The Root of Jesse will spring up, one who will arise to rule over the nations; the Gentiles will hope in him.)

The last quotation refers to the scion from Jesse, probably referring to Hezekiah in whom people, seeking after God, would put their hope. Paul applies this prophetic chorus to the humble Christ as ruler and hope of Jews and Gentiles in their united praise of God. In his mission Christ fulfils the universal salvation of the nations. This quotation from the Prophets completes the Old Testament validation of Paul's declaration in verse 8-9.

Writing in Greek, quoting from a Greek translation of the Jewish Bible (LXX) to a congregation in Rome, Paul seemingly expects them to sing together in the lingua franca to express their faith in the Father of their mutual Lord, Jesus Christ (Malan, 1998:511). Singing was an essential 
and integral part of worship in Judaism, and Paul implements their practice of singing, as well as their songs as such, to early Christian worship (cf. Fee, 1993:671). The Christians in Rome consisted of Gentiles (Romans and Greek) and Jews. Thus Paul presents a compelling vision of the church as community of redeemed Jews and Gentiles, praising God together for his faithfulness and mercy, made possible by Christ (Wagner, 1997:473 ff).

\subsection{Corinthians 14:15-17 and 26}

Paul writes 1 Corinthians to a church with a cosmopolitan composition (Lategan, 1984:59). In 1 Corinthians 13-14 he discusses the gifts of the Spirit. Al these gifts ought to be used in worship to build up one another (1 Corinthians 14:3) (cf. Hoon, 1969:482-497).

In 1 Corinthians 14:15-17 Paul uses musical references in his argumentation to explain the value of the gifts. He refers to real musical activity.

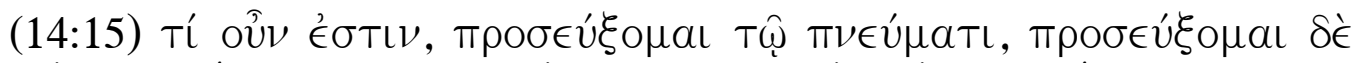

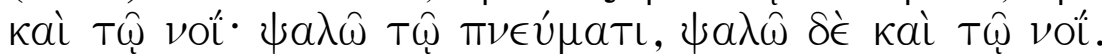

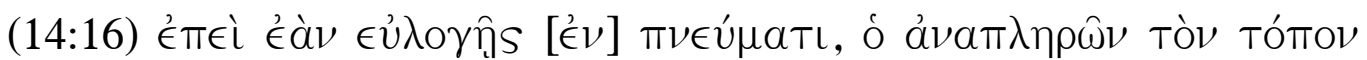

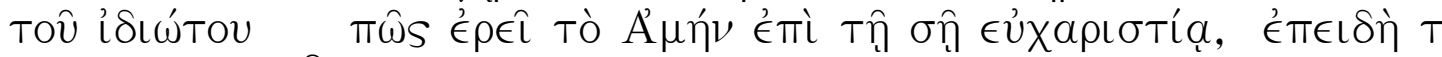

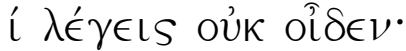

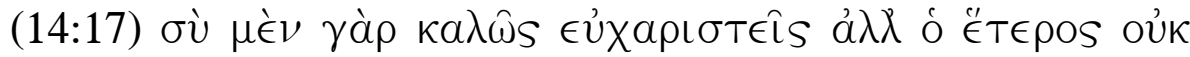

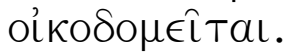

(So what shall I do? I will pray with my spirit, but I will also pray with my mind; I will sing with my spirit, but I will also sing with my mind. If you are praising God with your spirit, how can one who finds himself among those who do not understand say "Amen" to your thanksgiving, since he does not know what you are saying? You may be giving thanks well enough, but the other man is not edified.)

Along with prayer, hymn singing $(\psi a \lambda \lambda \in \iota \nu)$ is inspired by God, but should be intelligible. One should partake of these practices with mind and with spirit (cf. Eddy, 1983:12-16). The Greco-Roman religions had a shamanistic idea of prophecy accompanied by trance. Traces of this idea might have been present among the Corinthian Christians. Paul at least recognised a kind of charismatic hymnody by singing in tongues 4 with unintelligible words (glossolalia) (Dunn, 1975:238). Paul argues that this should not be the case in the Christian religion (Callan, 1985:125-140). People praying and singing praise to God should do it with active minds to build up themselves and one another. Seen within the context of

$4 \quad$ Singing in tongues still occurs in the current charismatic movement. It sounds like a common chord almost in a drone-like fashion, with different individual voices elaborating the chord with more complex harmonies. 
Greek theory of music as described by Plato and Aristotle, the correct use of song and music could be a powerful instrument to build up a person's character. According to Greek mythology, song and music were created by gods and are given to people through the inspiration of the Muse to be used in religious ceremonies and the edification of human beings. Over and against Greek mythology, Paul describes the inspiration to song and music as a gift from God. It is to be used for praise and thanksgiving to God (14:16). It also serves as instruction in the gathered community (14:17).

In 1 Corinthians 14:26 Paul again takes up the theme of song and music as one of a variety of gifts God gives to the church.

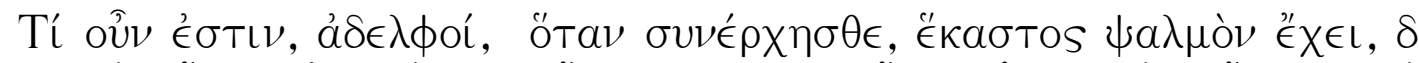

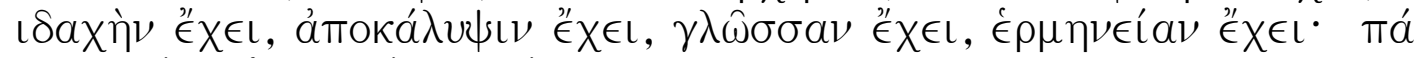

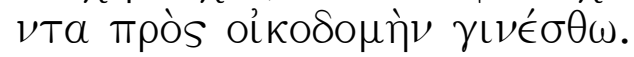

(What then shall we say, brothers? When you come together, everyone has a hymn, or a word of instruction, a revelation, a tongue or an interpretation. All of these must be done for the strengthening of the church.)

When the church come together for worship, individuals have something to contribute. One kind of contribution is that of singing a hymn. Here the meaning is that someone will have a song, presumably of his own composition, or will even sing spontaneously (Dunn, 1975:238; Fee, 1993:671). According to Greek traditions of music, performances were usually based on solo improvisation. While singing, music was created anew, using certain traditional musical formulas. Within this frame of mind, Paul probably refers to songs composed on the spur of the moment due to the inspiration of the Spirit. In context of the different gifts of the Spirit, these songs of praise are to be seen as gifts for edifying the congregation's faith in Jesus Christ (14:3). Paul is pleased with each member's contribution to liturgy - on condition that it edifies the church.

\subsection{Ephesians 5:19}

In Ephesians 5:19 Paul encourages his readers to praise God with song and music. This act distinguishes the behaviour of a believer from that of an unbeliever.

In 5:3-14 Paul refers to light and darkness to compare the behaviour of the believing community in contrast with unbelieving outsiders. He continues in 5:15-20 to describe wise living in contrast to foolish and reckless living. A wise person is one with insight into the norm of life given by the Lord $(5: 15,17)$, and one having the insight to apply it to everyday life (5:21 ff.). The contrast between the two conditions also 
becomes evident from the way people are elevated. The foolish person is filled with wine, but the wise with the Holy Spirit (cf. Gosnell, 1993: $363 \mathrm{ff}$.). The foolish person is excited as a result of drunkenness. The wise person is elevated because of the enlightenment and inspiration of the Holy Spirit (Salmon, 1951:363).

The bad influence of drunkenness leads a person to become unwise (5:15) and foolish (5:16). Drunkenness leads towards dissipation, recklessness and most probably to filthy drinking songs. Drunkenness in the Hellenistic world was quite common (Grosheide, 1960:83). In contrast to drunkenness, Spirit-filled persons also sing psalms, hymns and spiritual songs in worship of God to one another.

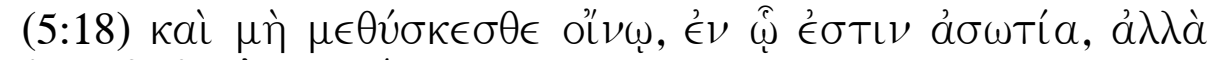

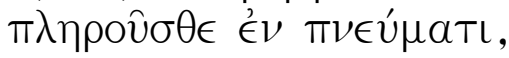

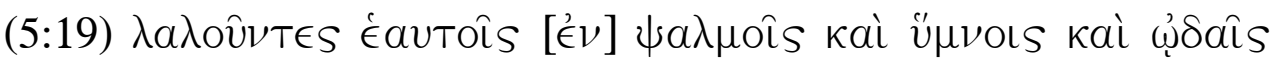

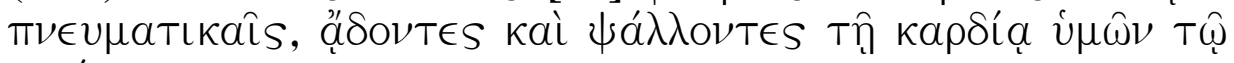
кupí

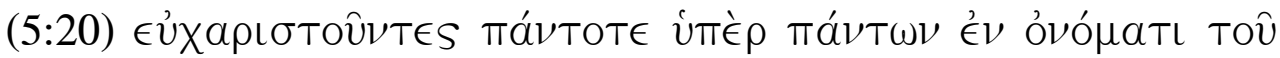

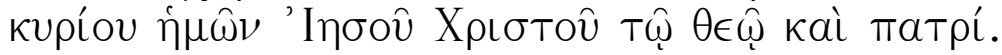

(Do not get drunk on wine, which leads to debauchery. Instead, be filled with the Spirit. Speak to one another with psalms, hymns and spiritual songs. Sing and make music in your heart to the Lord, always giving thanks for everything to God the Father, in the name of our Lord Jesus Christ.)

When reading Ephesians 5:18, knowing the way the Greeks and Romans worshipped their gods with song, a further connotation to Paul's words seems probable. Their worship to the god of the vine, Bacchus (according to the Romans) or Dionysos (according to the Greeks) was known for its emotional and mass ecstasy (Drumwright, 1977:127; Van Roon, 1976:135). Bacchus or Dionysos was the cheerful god of ecstasy. During their worship ritual, people were filled with the fruit of the wine and became drunk, believing to be filled with the god and being "high" to their god. After a bemusing and outrageous dance the revealer fell into a trance and received a message from Dionysos (Blaiklock, 1977:128129). Paul contrasts this behaviour at the Dionysos feasts to the worship of the Lord Jesus Christ and his Father. The Christian community should rather be filled with the Holy Spirit to sing in an elevated manner in honour of God.

The contrast is clear. A person, who is filled with the fruit of the vine and Diononysos, behaves foolishly and recklessly. With foolish songs that person has a bad influence on his or her community. Typical elements of the Dionysion intoxication were forgetfulness of self, excess and a barbaric lust of life. Such behaviour is not fitting for a believer. A believer 
should be filled with the Holy Spirit. A person who is filled with the Holy Spirit is guided by the Spirit. Such a person celebrates the truth, and exercises the influence of the Lord on the world. He or she receives insight into the will of the Lord, and has the insight to apply it to everyday life.

By singing he or she finds out how the Lord wants him or her to live. By means of the songs of the congregation in which wholehearted praise is offered to God, the believers build up one another in their faith (Griffith, 1995:37 ff.). In Jewish and Greek musical tradition, it was believed that song and music had the power and mandate to teach (cf. Payton, 1994:81-84). Song and music had a dominant role as moral pillar of the political and educational structure to create moral qualities and effects. Paul most probably refers to that connotation of music in Ephesians 5:18 ff.

Paul encourages the Christians to honour God with psalms, hymns and

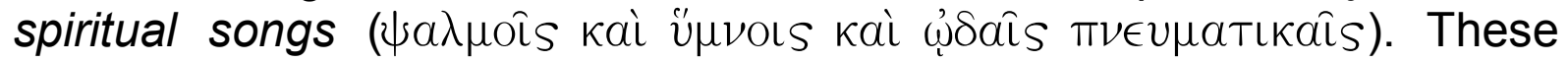
terms refer to a wide "array and diversity of songs" (Wiberg, 1998:35). These musical terms were known in the Greek, Roman and Jewish communities. In the Hellenistic world, psalms often testified to gladness and singing by the accompaniment of a string instrument. String instruments were used to create calmness and harmony in Jewish and Greek music. Jewish people might also have thought of the many Old Testament songs as a prototype of the psalms mentioned here. With a wide variety of psalms the Israelites celebrated the Lord and his great deeds in relation with his people. Hymns in the Hellenistic world were lofty songs, which often testified and recounted a heroic act of a late person ${ }^{5}$ or god. By these songs worshippers would express their respect for such a person or god. Paul uses this known term to encourage his readers to sing songs in which they express their trust in the Lord, his might and his salvation in numerous situations. Paul also refers to spiritual songs. The term "songs" is quite a neutral term for singing. In the Greek musical tradition, heroes were entertained with these songs during banquets. These heroic songs were mostly sung in an improvised manner and were believed to have originated directly from divine inspiration. Paul probably referred to this kind of songs, but in honour of the Lord. These songs should be inspired by the Holy Spirit (Viljoen, 1990:250). honoured by hymns. 


\subsection{Colossians 3:16}

Colossians and Ephesians are closely related 6 and consequently is the relation between Colossians 3:16 and Ephesians 5:18-19. Once again, in Colossians 3:16, Paul describes song and music in his discussion of the contrast between a people living the old life and the new life. With their psalms, hymns and spiritual songs the members admonish one another to put to death the earthly desires in them, and clothe themselves with the qualities of Christ (3:5-15).

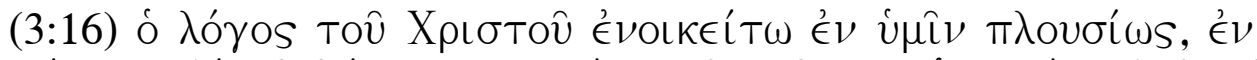

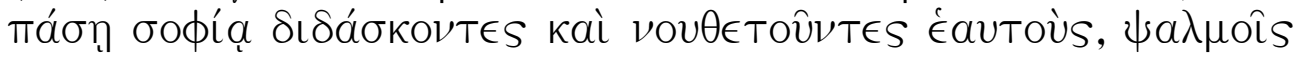

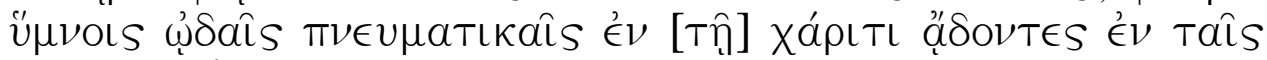

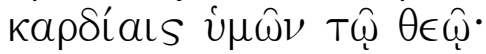

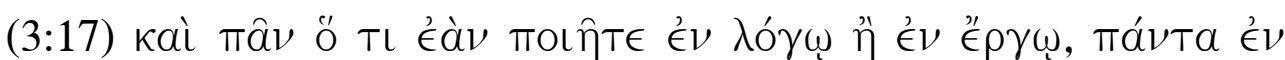

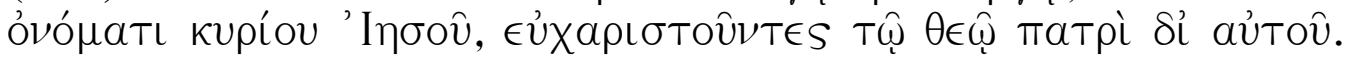

(Let the word of Christ dwell in you richly as you teach and admonish one another with all wisdom, and as you sing psalms, hymns and spiritual songs with gratitude in your hearts to God. And whatever you do, whether in word or deed, do it all in the name of the Lord Jesus, giving thanks to God the Father through him.)

Most remarkable is the parallel between being filled with the Spirit ( $\left.\pi \lambda \eta \rho \circ \hat{v} \sigma \theta \in \epsilon^{\prime} \nu \pi \nu \in \dot{u} \mu a \tau \iota\right)$ (Ephesians 5:18) and being filled with the Word

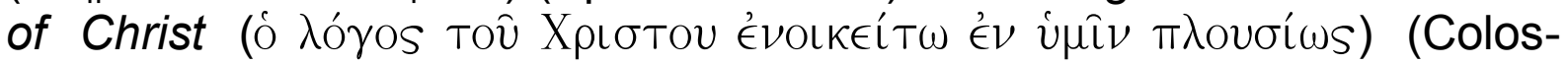
sians 3:16). This indicates the close link between the work of the Spirit and the Word in believers' lives. Reading these verses with the connotation of the Hellenistic Dionysos and Bacchus cult in mind, the meaning of Paul's admonition becomes more clear. In the Hellenistic religious ceremonies the worshipper would believe that he is filled by the presence and being of his god by means of the wine, and then, in an outrageous trance would speak the word from his god. In contrast to the Hellenistic worship, believers being filled by the Holy Spirit would speak out words and insights given by the Holy Spirit. In such a way the Word of Christ would play a comprehensive role among them, forming the centre of their interest. The Word of Christ would form the source and substance of their singing while bowing to Christ's authority. While singing, Christians ministered the word of Christ to one another so that the word indwelled the corporate life of the church (Buchanan, 1998:1720).

This edifying role of song and music correlates with the Greek theory of music. Music was concerned with the pursuit of truth and beauty.

6 Because of this close relation between Colossians an Ephesians, some scholars question the authorship of one or both of these letters. Consult my first footnote. 
According to Plato and Aristotle, this should be the most important use of song and music. Paul writes that members should teach and admonish one another in their pursuit of truth, very much the way prescribed by the Greek theory of music. Song and music were not only vehicles of praise ("to the Lord", "to God"), but also served as a means of instruction and admonishing one another. The song could perhaps be more easily remembered than mere words of teaching and could perhaps be less painful than mere words of admonishing (Dunn, 1975:239). The mutual edification of one another could probably happen by means of responsorial, antiphonical and/or solo singing, typical of Jewish music.

Thus Paul advises Spirit-prompted singing by which believers would instruct one another and glorify God by witnessing the rich dwelling of the word of Christ among them. Though psalms, hymns and spiritual songs are primarily the means of the congregation's worship of God, it is also a very effective teaching aid (Malan, 1998:522). Regarding contents, Christian psalms, hymns and spiritual songs should therefore contain both devotional and doctrinal facets.

\section{Conclusion}

Knowledge of the Greek, Jewish and Roman musical traditions are necessary for a better understanding of passages in the Pauline writings in which he refers to song and music. In these passages he apparently presupposes knowledge of these traditions from his first readers.

Paul encourages Christians in a Hellenised world, knowledgeable of Greek, Roman and Jewish musical traditions to praise God in unison. This is very much so in Romans 15:9-12, 1 Corinthians 14:15-17, 26, Ephesians 5:19 and Colossians 3:16. The modern exegete attains a better insight in what Paul meant in each of these references to music, when he also takes notice of these various musical traditions known in the Hellenistic world.

Thus, even today, this explanation and encouragement could be applicable to Christians in yet another time, environment and with different cultural origins. Apart from a better understanding of Paul, Christians can unite in praise and worship to the triune God.

\section{Bibliography}

ABRAHAM, G. 1985. The concise Oxford history of music. Oxford : Oxford University Press.

ARISTOTLE. Politics. (The Loeb Classical Library.) London : Heinemann. 1932.

BLAIKLOCK, E.M. 1977. Dionysos. (In Tenney, M.C., ed. The Zondervan Pictorial Encyclopaedia of the Bible. Volume 5. Michigan : Zondervan. p. 128-129.) 
BLOEM, G.N. 1985. Skrif en lied. (In Smuts, A.J., red. Die Woord aan die werk. Oor die kerklied, prediking, kategese. Referate van die SA Werkgemeenskap vir Praktiese Teologie. 1983-1985. Pretoria : NG-Kerk. p. 46-53.)

BUCHANAN, C. 1998. Doctrine and worship. Evangel, 16(1):17-20.

CALLAN, T. 1985. Prophecy and ecstacy in Greco-Roman religions and in 1 Corinthians. Novum Testamentum, 21(2):125-140.

CRANFIELD, C.E.B. 1979. A critical and exegetical commentary on the Epistle to the Romans. Edinburgh : Clark.

CRANFIELD, C.E.B. 1985. Romans. A shorter commentary. Grand Rapids : Eerdmans.

DRUMWRIGHT, H.L. 1977. Dionysia. (In Tenney, M.C., ed. The Zondervan Pictorial Encyclopedia of the Bible. Volume 5. Michigan : Zondervan. p. 127.)

DUNN, J.D.G. 1975. Jesus and the Spirit. London : SCM.

DU TOIT, A.B. 1993. Die Kirche als doxologische Gemeinschaft im Romerbrief. Neotestamentica, 27(1):69-77.

EDDY, G.T. 1983. With the understanding. Expository Times, 95(1):12-16.

FEE, G.D. 1993. The first epistle to the Corinthians. Grand Rapids : Eerdmans.

FLOOR, L. 1978. Persone rondom Paulus. Pretoria : NG Kerkboekhandel.

FLOOR, L. 1995. Efeziërs - Eén in Christus. Commentaar op het Nieuwe Testament. Derde serie. Kampen : Kok.

FOHRER, G, 1968. Introduction to the Old Testament. London : SPCK.

GOSNELL, P.W. 1993. Ephesians 5:18-20 and mealtime propriety. Tyndale Bulletin, 44(2):363-371.

GRIFFITH, F. 1995. The role of singing in the life and worship of the church. Reformation and Revival Journal, 4(4):37-60.

GROSHEIDE, F.W. 1960. De Brief van Paulus aan de Efeziërs. Kampen : Kok.

GROUT, D.J. 1960. A history of Western music. New York : Norton.

GUTHRIE, D. 1970. New Testament introduction. Leicester : Inter-Varsity.

HOON, P.W. 1969. Liturgy of gamesmanship? Religion in Life, 38(4):482-497.

HÖWELER, C. 1951. Inleiding tot de Muziekgeschiedenis. Amsterdam : Paris.

JONES, I.H. 1986. Musical instruments in the Bible. Part I. Biblical Theology, 37:101115.

JOSEPHUS. Antiquitates. Grand Rapids : Kregel Publications. 1964.

KEUCHENIUS, M.. ed. et al. 1977. Muziek onder woorden. Utrecht : Kluwerpers.

KLOPPENBURG, W.C.M. 1963. Muziek door de eeuwen. Amsterdam : Broekmans \& Van Poppel.

LAMB, J.A. 1962. The Psalms in Christian worship. London : Faith.

LATEGAN, B.C. 1984. 1 Korintiërs. (In Du Toit, A.B., red. Handleiding by die Nuwe Testament. Volume V. Pretoria : NG Kerkboekhandel. p. 57-79.)

LOUW, J.P. 1981. Fasette van die Hellenisme. Pretoria : Universiteit van Pretoria.

MALAN, F.S. 1998. Church singing according to the Pauline Epistles. Neotestamentica, 32(2):509-524.

NIETZCHE, F.W. 1917. Die Geburt der Tragodie: unzeitgemasse Betrachtungen. Leipzig : Kroner.

OESTERLEY, W.O.E. 1941. The Jews and Judaism during the Greek period: Background of Christianity. London : Society of Promoting Christian Knowledge.

OESTERLEY, W.O.E. 1965. The Jewish background of Christian liturgy. London : Oxford University Press.

PELSER, G.M.M. 1984. Die Brief aan die Romeine. (In Du Toit, A.B., red. Handleiding by die Nuwe Testament. Volume V. Pretoria : NG Kerkboekhandel. p. 41-56.) 
PAYTON, L.R. 1994. A chief musician is a pastor-teacher. Reformation and Revival Journal, 3(4):81-84.

PHILO. Philo. (The Loeb Classical Library.) London : Heinemann. 1949.

PLATO. Republic. (The Loeb Classical Library.) London : Heinemann. 1953.

SAA, G. 1993. Rom. 15, 7-13 - als Summe des Romerbriefs gelesen. Evangelische Theologie, 53(6):510-527.

SACHS, C. 1943. The rise of music in the Ancient world: East and West. New York : Norton.

SALMON, S.D.F. 1951. The Epistle of the Ephesians. The Expositor's Greek Testament. Grand Rapids : Eerdmans.

SCHLIER, H. 1969. Halleluja. (In Kittel, G., ed. Theological Dictionary of the New Testament, I. Grand Rapids : Eerdmans. p. 264.)

SOKOLOWSKI, F. 1959. From the history of the worship of Apollo at Actium. Harvard Theological Review, 52:215-221.

VAN DYK, P.J. 1991. Music in Old Testament Times. Old Testament Essays, 4:373380.

VAN ROON, A. 1976. De lied van Paulus aan de Epheziers. Nijkerk : Callenbach.

VILJOEN, F.P. 1990. Die betekenis van "Psalmois, Humnois" en "Odais Pneumatikais" in Kolossense 3:16 en Efesiërs 5:19. Potchefstroom : Potchefstroomse Universiteit vir CHO. (Th.D. Thesis.)

WAGNER, J.R. 1997. The Christ, Servant of Jew and Gentile: A fresh approach to Romans 15:8-9. Journal of Biblical Literature, 116(3):473-485.

WÖRNER, K.H. 1973. History of music. New York \& London : The Free Press.

WIBERG, G.V. 1998. A covenanter looks at praise songs. Covenant Quarterly, $56(2): 34-41$.

\section{Kernbegrippe:}

Griekse musiektradisie

Joodse musiektradisie

Pauliniese briewe: rol van lied en musiek

Romeinse musiektradisie

\section{Key concepts:}

Greek musical tradition

Jewish musical tradition

Pauline Epistles: role of song and music

Roman Jewish musical tradition 